\title{
Aboveground Biomass and Organic Carbon of Native Araucaria Angustifolia (Bertol.) Kuntze
}

\author{
Mailson Roik ${ }^{1}$ (1) 0000-0002-8676-2692 \\ Sebastião do Amaral Machado ${ }^{1}$ (1) 0000-0003-1010-4623 \\ Afonso Figueiredo Filho ${ }^{2}$ (D) 0000-0001-9965-7851 \\ Carlos Roberto Sanquetta ${ }^{3}$ (1) 0000-0001-6277-6371 \\ Emilio Carlos Zilli Ruiz ${ }^{2}$ (1) 0000-0002-8672-2711
}

\begin{abstract}
The aim of this study was to quantify the aboveground biomass and organic carbon of Araucaria angustifolia (Bertol.) Kuntze in a Mixed Ombrophilous Montane Forest in the state of Paraná. The aboveground biomass determination was carried out according to the direct method, using 29 trees with Diameter at Breast Height (DBH) $\geq 40 \mathrm{~cm}$. The trees were felled, cubed and weighed by compartments, which were sampled for determining moisture and carbon content. The average aerial biomass and carbon were $2,126.5 \mathrm{~kg} \mathrm{ind}^{-1}$ and $935.8 \mathrm{~kg} \mathrm{ind}^{-1}$, respectively. The moisture content resulted in a mean individual accumulation of 2,376.6 liters ind ${ }^{-1}$ of water. Age did not necessarily result in higher volume production but resulted in higher stem biomass production. Organic carbon accumulation by native A. angustifolia trees should support carbon credits as an incentive for the conservation of araucaria and Mixed Ombrophilous Forest fragments.
\end{abstract}

Keywords: carbon credit, carbon sequestration, Mixed Ombrophilous Forest.

\section{INTRODUCTION AND OBJECTIVES}

The relationship between the carbon dioxide $\left(\mathrm{CO}_{2}\right)$ concentration in the atmosphere and the increase in the average temperature of the planet (Dlugokencky \& Tans, [2017?]) raises concerns about the impacts of increasing concentrations of greenhouse gases (GHG) on the world climate, more recently and specifically in Brazil (PBMC, 2014a, 2014b). In parallel, there is growing interest in studies on the ability of forests to remove $\mathrm{CO}_{2}$ from the atmosphere and to store carbon in their biomass (Caldeira et al., 2015).

The biomass forest volume is the controlling factor of the global carbon stock and its quantification is necessary to understand the productivity, nutrient allocation and carbon cycles in individuals or ecosystems (Higuchi \& Carvalho, 1994; Silveira et al., 2008), while also serving as a basis for future predictions of climate change. Watson (2009) corroborates that quantifying carbon in forest ecosystems and their changes from human activities is the first step to better represent forests in climate policy at regional, national and global scales.

According to Caldeira et al. (2015), determining the amount of carbon stored in tree individuals and consequently in forests or forest stands can be accomplished by quantifying the biomass and then determining the carbon concentration. Biomass can be quantified by the direct method or estimated by the indirect method. Quantification means actual measurement performed directly in the field or field-determined weight such as weighing some tree compartment with a scale or dynamometer (Higuchi \& Carvalho, 1994). Estimating biomass and carbon by the indirect method consists in using easily obtainable variables, and thus not necessitating the felling of trees (Silveira et al., 2008). These same authors pointed

\footnotetext{
${ }^{1}$ Universidade Federal do Paraná (UFPR), Curitiba, PR, Brasil

${ }^{2}$ Universidade Estadual do Centro-Oeste (Unicentro), Irati, PR, Brasil

${ }^{3}$ BIOFIX Research Center, Curitiba, PR, Brasil
} 
out that estimates can be made through quantitative and mathematical relationships such as biomass factors (expansion and reduction), allometric models that use data from forest inventories (DBH, height and volume), data from remote sensing (satellite images), and using a database in a geographic information system (GIS). Recent research has evaluated the use of Artificial Intelligence techniques for estimating biomass and carbon (Schoeninger et al., 2008; Sanquetta et al., 2013; Sanquetta et al., 2015). Indirect methods should not be used without the adjustment and prior calibration of the equations, therefore needing to be used in conjunction with direct methods (Balbinot et al., 2009).

According to Caldeira et al. (2004), the conservation of natural forests basically depends on the knowledge of their dynamics. However, information on the productive capacity of natural forests, specifically the Mixed Ombrophilous Forest, is difficult to monitor, and thus it is subsequently difficult to monitor the growth and regeneration dynamics of these ecosystems. The same authors also affirmed that this information is important to enable exploitation of natural forests in the form of sustained management, or also to subsidize actions for their conservation.

In the works performed in a Mixed Ombrophilous Forest, biomass quantification is usually done by the direct method (plot method). In this case, generally a few samples of limited size are evaluated, due to the inherent difficulties of the evaluation associated with the dimensions of A. angustifolia. Therefore, the number of native individuals of the sampled species is reduced. This is because the conditions of individuals established in forest stands differ from those corresponding to individuals established in native fragments, which impairs using such information as a comparative basis. In this sense, a deeper investigation of biomass and carbon values in native A. angustifolia individuals is necessary.

According to Socher et al. (2008), in order to conduct reliable biomass studies it is necessary (at least in the first approach) to perform a destructive sampling, in which the various components of the tree are analyzed, and there is separation and specification of these components varying according to the type of forest and the goals to be achieved.

Nevertheless, some biomass quantification studies have been carried out in the last decades, a large part of them, however, in tropical forests (Barni et al., 2016; Djomo \& Chimi, 2017; Henry et al., 2010; Ketterings et al., 2001; Lima et al., 2012; Nogueira et al., 2008). In the Mixed Ombrophilous Forest, studies conducted by Caldeira et al. (2004), Socher et al. (2008), Balbinot et al. (2009), Watzlawick et al. (2009), Watzlawick et al., (2011) and Watzlawick et al. (2012) may be highlighted. In forest stands of the Araucaria angustifolia species, studies have been performed by Watzlawick et al. (2003),
Dallagnol et al. (2011), Schumacher et al. (2011), Mognon et al. (2013), Sanquetta et al., (2014) and Caldeira et al. (2015).

Considering the aforementioned, the objective of the present study was to generate information on the aboveground biomass and individual organic carbon values in native Araucaria angustifolia trees, as well as to verify the relation of the total aboveground biomass and the different components with the variables of volume and age.

\section{MATERIALS AND METHODS}

This study was developed in a Montane Mixed Ombrophilous Forest fragment located in the sub-basin of the Imbituvão River, Assungui community of the Fernandes Pinheiro municipality, in the state of Paraná. This municipality is in the Mid-South region of the state $\left(25^{\circ} 27^{\prime} \mathrm{S}\right.$ and $\left.50^{\circ} 35^{\prime} \mathrm{W}\right)$, at an altitude of $893 \mathrm{~m}$ (Wrege et al., 2012). It borders the municipalities of Imbituva, Teixeira Soares, São João do Triunfo, Rebouças, and Irati (IBGE, [2017?]).

The climate of the region is classified as Cfb (Köppen), Subtropical Humid Mesothermal. More specifically, it is characterized by fresh summers and winters with severe frosts, without a dry season. The average annual temperature is $19^{\circ} \mathrm{C}$, the average minimum monthly temperature is $13.9^{\circ} \mathrm{C}$ and the average maximum monthly temperature is $26.1^{\circ} \mathrm{C}$. The annual precipitation varies between 1,400 and $1,600 \mathrm{~mm}$ and the relative humidity of the average air is $74 \%$ (Wrege et al., 2012).

The determination of biomass in the field was performed according to the direct quantification method by sampling 29 trees with $\mathrm{DBH} \geq 40 \mathrm{~cm}$ (Table 1) randomly distributed in the fragment, aiming to cover the diametric variability.

Table 1. Volume, age and number of individuals sampled from the Araucaria angustifolia species.

\begin{tabular}{llcccc}
\multicolumn{2}{c}{ DBH Class $(\mathbf{c m})$} & $\mathbf{4 0 - 5 0}$ & $\mathbf{5 0 - 6 0}$ & $\mathbf{6 0 - 7 0}$ & Total \\
Sampled & Males & 3 & 7 & 3 & 13 \\
individuals & Females & 9 & 6 & 1 & 16 \\
& Total & 12 & 13 & 4 & 29 \\
\multirow{3}{*}{$\begin{array}{l}\text { Volume } \\
\left(\mathrm{m}^{3} \text {.individual }\right.\end{array}$} & Minimum & 1.37 & 2.34 & 3.89 & 1.37 \\
& Mean & 1.99 & 3.31 & 4.64 & 2.94 \\
& Maximum & 2.74 & 4.32 & 5.30 & 5.30 \\
Age (years) & Minimum & 80 & 87 & 99 & 80 \\
& Mean & 99 & 101 & 126 & 104 \\
& Maximum & 111 & 119 & 188 & 188 \\
\hline
\end{tabular}

DBH: diameter at breast height.

Sampling individuals only in diameter classes equal to or greater than $40 \mathrm{~cm}$ relates to the origin of the data used 
in this research, which comes from a sustainable forest management experiment for Araucaria forest in small farms. Such experiment implemented a methodology considering the application of different cutting intensities of Araucaria exclusively in the largest diameter classes.

The individuals were felled and the dendrometric variables were initially obtained: DBH, total height and commercial height (height corresponding to the first verticil). Relative volume measurement of the stem with bark was carried out by taking measures of diameter with bark at $0.1 ; 0.7$; and $1.3 \mathrm{~m}$, from there to 15,25 , up to $95 \%$ of the total height. The volume was calculated by the Smalian formula, with the last section being considered as a cone.

After measuring the tree bark volume, each tree had its components (leaves, branches, commercial stem with bark and non-commercial stem with bark) separated, weighed and sampled. The male reproductive structures were weighed along with the leaves. Female reproductive structures were disregarded from the analysis since few were found at the time of data collection.

Each component was weighed separately, obtaining the green biomass using a dynamometer with a capacity of 3,000 kg. The stem with bark was sectioned based on an optimized assortment of logs (which varied by 3,4 or $5 \mathrm{~m}$ ). Quantification of the total bark weight was calculated based on the percentage of the stem bark obtained by measuring the volume of the logs and the non-commercial stem.

For sampling purposes, the stem was divided into commercial stem (corresponding section from the base to the first verticil) and non-commercial stem (section between the first verticil and total height). To sample the wood with bark of the commercial stem, three discs of approximately $5 \mathrm{~cm}$ thickness were removed from the base, middle and end of the section. For the non-commercial stem, a 50\% sample of the crown length was withdrawn in such a way that it contemplated a verticil and a space between verticils.

It was possible to determine the age of the trees by counting the growth rings of the disc taken from the base of each individual. The ages were later related to the individual production of biomass and volume.

Sampling of the leaves was performed in the lower, middle and upper third of the crown. The same procedure was adopted for the branches component, with samples being taken at the end, middle and base of the branches.

The samples were taken to the laboratory and dried in an air circulation greenhouse at a temperature of $65^{\circ} \mathrm{C}$ until reaching constant weight for further determining the moisture content and preparation for chemical analysis of the organic carbon content. To calculate the dry biomass of the commercial stem, the mass-weighted average moisture content of the lower and upper discs (samples) relative to that section was used.

In order to determine the carbon content, the samples were first fragmented using a planing saw, crushed in a Willey and Croton mill with a 20 -mesh sieve and then analyzed by the direct combustion method using a C-144 LECO elemental analyzer. Through this method, the sample is placed in a pure oxygen environment with a temperature typically set at $1,350{ }^{\circ} \mathrm{C}$ and is then subjected to complete combustion, releasing the carbon as carbon dioxide, which is measured by infrared sensors. The instrument converts the result to a percentage using a predefined equation in the software that considers sample weight, calibration, and known moisture value (LECO, 2008).

The bark was separated from the wood to determine the individual carbon content for each fraction. The samples were grouped in a composite sample to determine the carbon content of the commercial stem. After determining the organic carbon content in each sampled fraction, it was then multiplied by the dry biomass, thereby obtaining the amount of organic carbon per compartment.

\section{RESULTS AND DISCUSSION}

The mean individual aboveground biomass production

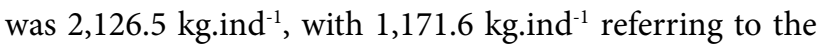
wood of the stem; $418.7 \mathrm{~kg}^{-1 \mathrm{ind}^{-1}}$ to the stem bark, $406.1 \mathrm{~kg}$. ind $^{-1}$ to the branches; and $130.1{\mathrm{~kg} . i n d^{-1}}^{-1}$ to the leaves (Table 2).

Table 2. Absolute and relative dry biomass values of Araucaria angustifolia per DBH class for each evaluated component and for the total.

\begin{tabular}{|c|c|c|c|c|c|c|c|c|c|c|}
\hline \multirow{2}{*}{$\begin{array}{l}\text { DBH class } \\
(\mathrm{cm})\end{array}$} & & \multicolumn{2}{|c|}{ Wood } & \multicolumn{2}{|c|}{ Bark } & \multicolumn{2}{|c|}{ Branches } & \multicolumn{2}{|c|}{ Leaves } & \multirow{2}{*}{$\frac{\text { Total }}{\left(\text { kg.ind }^{-1}\right)}$} \\
\hline & & $\left(\mathrm{kg} \cdot\right.$ ind $\left.^{-1}\right)$ & (\%) & $\left(\mathrm{kg}\right.$.ind $\left.{ }^{-1}\right)$ & (\%) & $\left(\mathrm{kg}\right.$.ind $\left.^{-1}\right)$ & $(\%)$ & $\left(\mathrm{kg} \cdot\right.$ ind $\left.^{-1}\right)$ & $(\%)$ & \\
\hline \multirow{3}{*}{$40.0-49.9$} & Minimum & 557.4 & 53.7 & 251.6 & 17.5 & 89.0 & 7.6 & 30.6 & 1.8 & 960.3 \\
\hline & Mean & 829.5 & 57.8 & 296.2 & 20.6 & 225.3 & 15.7 & 83.7 & 5.8 & $1,434.7$ \\
\hline & Maximum & $1,149.7$ & 65.5 & 405.6 & 26.2 & 416.5 & 25.2 & 188.6 & 10.4 & $1,865.9$ \\
\hline \multirow{3}{*}{$50.0-59.9$} & Minimum & 895.5 & 47.2 & 323.5 & 14.5 & 67.1 & 4.9 & 59.2 & 4.3 & $1,362.4$ \\
\hline & Mean & $1,269.9$ & 54.5 & 454.1 & 19.5 & 462.8 & 19.9 & 144.5 & 6.2 & $2,331.3$ \\
\hline & Maximum & $1,599.1$ & 65.7 & 608.7 & 25.0 & 712.5 & 26.8 & 227.1 & 8.0 & $2,882.8$ \\
\hline
\end{tabular}


Table 2. Continued....

\begin{tabular}{|c|c|c|c|c|c|c|c|c|c|c|}
\hline \multirow{2}{*}{$\begin{array}{l}\text { DBH class } \\
(\mathrm{cm})\end{array}$} & & \multicolumn{2}{|c|}{ Wood } & \multicolumn{2}{|c|}{ Bark } & \multicolumn{2}{|c|}{ Branches } & \multicolumn{2}{|c|}{ Leaves } & \multirow{2}{*}{$\frac{\text { Total }}{\left(\mathrm{kg}^{\text {ind }} \mathrm{d}^{-1}\right)}$} \\
\hline & & $\left(\right.$ kg.ind $\left.^{-1}\right)$ & $(\%)$ & $\left(\right.$ kg.ind $\left.^{-1}\right)$ & $(\%)$ & $\left(\right.$ kg.ind $\left.^{-1}\right)$ & $(\%)$ & $\left(\mathbf{k g} \cdot\right.$ ind $\left.^{-1}\right)$ & $(\%)$ & \\
\hline \multirow{3}{*}{$60.0-69.9$} & Minimum & $1,580.4$ & 51.5 & 532.8 & 16.4 & 615.4 & 19.5 & 118.9 & 3.0 & $3,037.8$ \\
\hline & Mean & $1,878.3$ & 53.1 & 671.6 & 19.0 & 764.3 & 21.6 & 222.4 & 6.3 & $3,536.6$ \\
\hline & Maximum & $2,158.0$ & 54.3 & 803.8 & 20.2 & 895.6 & 24.3 & 259.8 & 8.6 & $3,976.2$ \\
\hline \multicolumn{2}{|c|}{ Weighted mean } & $1,171.6$ & 55.1 & 418.7 & 19.7 & 406.1 & 19.1 & 130.1 & 6.1 & $2,126.5$ \\
\hline
\end{tabular}

$\mathrm{DBH}$ : diameter at breast height.

The highest relative values of dry wood biomass and stem bark were observed in the smallest diameter class (center of $45 \mathrm{~cm}$ class) followed by the intermediate class (center $55 \mathrm{~cm}$ class), meaning that the relation between size (by the DBH class) and the dry biomass percentage of the wood and stem bark occurs inversely. The opposite result was observed for the dry biomass of the branches and leaves, where the highest and lowest relative values were observed in the largest and lowest diameter class, respectively. For the average of all the evaluated trees, $55.1 \%$ of the dry biomass came from the stem wood, $19.7 \%$ from the stem bark, $19.1 \%$ from the branches and $6.1 \%$ from the leaves.

An average of $935.8 \mathrm{~kg}$. ind $^{-1}$ accumulated organic carbon was found, with $514.7 \mathrm{~kg}^{-i n d^{-1}}$ corresponding to the stem wood; $185.4 \mathrm{~kg} . i n d^{-1}$ in the stem bark; $178.6 \mathrm{~kg}$. ind $^{-1}$ in the branches; and $57.1{\mathrm{~kg} . i n d^{-1}}^{-1}$ in the leaves, as can be seen in Table 3 .

In studying the total biomass production of a 27-year-old stand of A. angustifolia in Quedas do Iguaçu, PR, Schumacher et al. (2011) found an average individual yield of $778.6 \mathrm{~kg}$. ind $^{-1}$, including $105.6 \mathrm{~kg}$.ind ${ }^{-1}$ corresponding to root biomass (13.6\% of the total). The individual aboveground biomass found was $672.9 \mathrm{~kg} . \mathrm{ind}^{-1}$, with $402.9 \mathrm{~kg}$.ind ${ }^{-1}$ for the stem wood corresponding to $59.9 \%$ of the aboveground biomass, with $101.0 \mathrm{~kg}^{- \text {ind }^{-1}}\left(15.0 \%\right.$ - branches), $100.6 \mathrm{~kg}^{- \text {ind }^{-1}}(14.9 \%$ stem bark), and $68.4 \mathrm{~kg}$. ind $^{-1}(10.2 \%$ - leaves $)$.

In evaluating aboveground biomass production in an A. angustifolia stand with ages ranging from 23 to 32 years old, in General Carneiro, PR, Caldeira et al. (2015) found an average biomass production of $369.5 \mathrm{~kg}$.ind ${ }^{-1}, 50.5 \%$ for stem wood, $24.3 \%$ for the stem bark, $16.5 \%$ for branches and $8.7 \%$ for leaves. In relation to the accumulated organic carbon, these authors found an average production of $156.8 \mathrm{~kg}^{-1 \text { ind }^{-1}}$, with $52.4 \%$ for the stem wood, $23.0 \%$ for the stem bark, $16.3 \%$ for the branches and $8.3 \%$ for the leaves.

Regarding the total biomass of a 30-year-old A. angustifolia stand also in General Carneiro, Watzlawick et al. (2003)

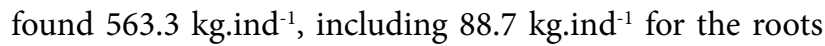
( $15.7 \%$ of the total). In relation to aboveground biomass, $48.3 \%$ corresponded to the stem wood, $28.3 \%$ to the stem bark, $15.2 \%$ to the branches and $8.2 \%$ to the leaves. The percentages of fixed carbon found were stem wood (50.0\%), stem bark (26.6\%), branches (15.0\%) and leaves (8.4\%) of a total of $245.4 \mathrm{~kg} \cdot$.ind $^{-1}$.

Table 3. Absolute and relative organic carbon values in Araucaria angustifolia per DBH class for each evaluated component and for the total.

\begin{tabular}{|c|c|c|c|c|c|c|c|c|c|c|}
\hline \multirow{2}{*}{$\begin{array}{l}\text { DBH class } \\
\quad(\mathrm{cm})\end{array}$} & & \multicolumn{2}{|c|}{ Wood } & \multicolumn{2}{|c|}{ Bark } & \multicolumn{2}{|c|}{ Branches } & \multicolumn{2}{|c|}{ Leaves } & \multirow{2}{*}{$\frac{\text { Total }}{\left(\mathrm{kg}^{\left.- \text {ind }^{-1}\right)}\right.}$} \\
\hline & & $\left(\right.$ kg.ind $\left.^{-1}\right)$ & $\%$ & $\left(\mathrm{~kg} \cdot \mathrm{ind}^{-1}\right)$ & $\%$ & $\left(\mathrm{~kg} \cdot \mathrm{ind}^{-1}\right)$ & $\%$ & $\left(k^{\prime} \cdot\right.$ ind $\left.^{-1}\right)$ & $\%$ & \\
\hline \multirow{3}{*}{$40.0-49.9$} & Minimum & 246.8 & 53.7 & 111.4 & 17.5 & 39.1 & 7.6 & 13.4 & 1.8 & 425.3 \\
\hline & Mean & 366.0 & 57.8 & 131.1 & 20.7 & 99.3 & 15.7 & 36.9 & 5.8 & 633.3 \\
\hline & Maximum & 510.1 & 65.4 & 179.7 & 26.2 & 183.3 & 25.1 & 82.0 & 10.3 & 827.8 \\
\hline \multirow{3}{*}{$50.0-59.9$} & Minimum & 395.6 & 47.1 & 143.9 & 14.6 & 29.5 & 4.9 & 26.4 & 4.4 & 602.7 \\
\hline & Mean & 558.1 & 54.4 & 201.1 & 19.6 & 203.9 & 19.9 & 63.5 & 6.2 & $1,026.6$ \\
\hline & Maximum & 701.6 & 65.6 & 268.9 & 25.1 & 313.0 & 26.8 & 100.1 & 8.0 & $1,273.6$ \\
\hline \multirow{3}{*}{$60.0-69.9$} & Minimum & 691.8 & 51.3 & 236.3 & 16.6 & 266.3 & 19.5 & 52.4 & 3.0 & $1,329.7$ \\
\hline & Mean & 819.7 & 52.9 & 297.4 & 19.2 & 334.1 & 21.6 & 97.1 & 6.3 & $1,548.2$ \\
\hline & Maximum & 941.7 & 54.0 & 356.7 & 20.4 & 394.8 & 24.2 & 113.3 & 8.5 & $1,745.6$ \\
\hline Weighted mean & & 514.7 & 55.0 & 185.4 & 19.8 & 178.6 & 19.1 & 57.1 & 6.0 & 935.8 \\
\hline
\end{tabular}

DBH: diameter at breast height. 
It is observed that the absolute mean values of aboveground biomass and organic carbon found in the present study are higher than the results obtained in studies carried out in stands of the same species (Caldeira et al., 2015; Schumacher et al., 2011; Watzlawick et al., 2003), mainly due to the age difference and consequently to the size of the individuals. According to Schumacher \& Caldeira (2001), biomass production tends to increase with age, and age and spacing are generally the factors that most interfere in the biomass distribution among the different tree components.

However, in analyzing the components separately, the percentage distribution of aboveground biomass of the Araucaria followed the same order observed for the accumulation of organic carbon, which is stem wood $>$ stem bark $>$ branches $>$ leaves, thus corroborating the results obtained by Sanquetta, Dalla Corte et al. (2003), Watzlawick et al. (2003), Schumacher et al. (2011) and Caldeira et al. (2015).

In comparing the results obtained with another conifer (Pinus taeda), Schumacher et al. (2013) estimated the stem wood at $69.1 \%$, and the stem bark at $6.7 \%$ of the aboveground biomass in a 27-year-old stand in Cambará do Sul, RS. For the same species, Watzlawick et al. (2013) estimated wood and bark biomass at $65.6 \%$ and $12.3 \%$, respectively, in a stand between 14 and 32 years of age in General Carneiro, PR. Thus, it is possible to affirm that A. angustifolia is a species that presents less relative biomass accumulation in the stem wood in comparison to P. taeda, which is partly related to the greater relative allocation in the bark. In the present study, there was $19.7 \%$ biomass accumulation in the stem bark. The results obtained by Sanquetta, Watzlawick et al. (2003) in P. taeda and A. angustifolia stands,
Watzlawick et al. (2003) for A. angustifolia, as well as Watzlawick et al. (2013) for P. taeda also corroborate this allocation pattern for the two species.

The organic carbon percentage values were very close to those of aboveground biomass, which is explained by the small variation in the carbon content in the different components, presented together with the moisture contents for each evaluated component (Table 4).

It is possible to observe that the carbon content presented little variation among the different components, and the stem wood, branches and leaves presented the same average content (44.0\%). The bark component of the stem had the highest organic carbon percentage, corresponding to $44.3 \%$ of the dry biomass. The carbon contents obtained in this study are similar to those of other studies, however they differ in the order of accumulation between some of the analyzed components, especially in the stem bark. Weber et al. (2003) found organic carbon content in the following order: stem wood (44.1\%), leaves (44.0\%), branches (41.7\%) and stem bark (40.1\%). Dallagnol et al. (2011) described the following percentages: stem wood and leaves (45.3\%), branches (44.5\%) and bark (43.1\%). Watzlawick et al. (2011) found the following contents: stem wood (43.4\%), branches (43.3\%), leaves (42.5\%), and stem bark (39.4\%).

According to Gonçalves et al. (2004), greater differences in total nutrient requirements are more frequent among species than among genotype variations of the same species. However, Barros \& Novais (1996) stated that plant nutrition and the consequent increase in biomass accumulation is best determined by the rainfall distribution that influences soil water availability as well as improved nutrient availability.

Table 4. Carbon and moisture content of Araucaria angustifolia per DBH class for each evaluated component.

\begin{tabular}{|c|c|c|c|c|c|c|c|c|}
\hline \multirow{2}{*}{$\begin{array}{l}\text { DBH class } \\
\quad(\mathrm{cm})\end{array}$} & & \multicolumn{3}{|c|}{ Moisture content (\%) } & \multicolumn{4}{|c|}{ Carbon content (\%) } \\
\hline & & Stem & Branches & Leaves & Wood & Bark & Branches & Leaves \\
\hline \multirow{3}{*}{$40.0-49.9$} & Minimum & 46.8 & 44.0 & 51.2 & 43.9 & 43.4 & 43.6 & 43.5 \\
\hline & Mean & 51.4 & 53.5 & 57.7 & 44.1 & 44.3 & 44.1 & 44.1 \\
\hline & Maximum & 54.8 & 57.8 & 66.7 & 44.4 & 44.5 & 44.5 & 44.5 \\
\hline \multirow{3}{*}{$50.0-59.9$} & Minimum & 49.1 & 47.6 & 51.5 & 43.4 & 44.1 & 43.5 & 43.1 \\
\hline & Mean & 52.8 & 53.9 & 56.3 & 43.9 & 44.3 & 44.1 & 44.0 \\
\hline & Maximum & 55.2 & 56.5 & 62.5 & 44.6 & 44.5 & 44.7 & 44.7 \\
\hline \multirow{3}{*}{$60.0-69.9$} & Minimum & 51.2 & 51.3 & 47.7 & 43.5 & 44.1 & 43.3 & 43.1 \\
\hline & Mean & 52.8 & 52.1 & 53.6 & 43.6 & 44.3 & 43.7 & 43.7 \\
\hline & Maximum & 53.8 & 52.9 & 61.5 & 43.8 & 44.4 & 44.1 & 44.1 \\
\hline \multicolumn{2}{|c|}{ Weighted mean } & 52.2 & 53.5 & 56.5 & 44.0 & 44.3 & 44.0 & 44.0 \\
\hline
\end{tabular}

DBH: diameter at breast height. 
The average moisture contents for the stem bark, branches and leaves were $52.2 \%, 53.5 \%$ and $56.5 \%$, respectively. This means that based on average aboveground biomass values (green and dry), the Araucaria trees with $\mathrm{DBH} \geq 40 \mathrm{~cm}$ accumulate an average of 2376.6 liters.ind $^{-1}$ of water in their structure (considering the water density equal to $1 \mathrm{~g} / \mathrm{cm}^{3}$ ), with $1,741.0$ liters.ind ${ }^{-1}$ in the stem wood and bark, 472.3 liters.ind ${ }^{-1}$ in the branches and 163.3 liters.ind $^{-1}$ in the leaves. Similar moisture contents were described by Watzlawick et al. (2003) in a stand of this species located in General Carneiro, PR.
The relationship between the volume, age and biomass of each component can be visualized in Figure 1. Different from what occurs between volume and age in equine stands where an increase in age leads to an increase in individual volume (Figueiredo Filho et al., 2015), this relationship does not always occur in native fragments due to all the factors that influence tree growth, especially those related to competition with adjacent individuals, mainly for space, light, water and nutrients. For example, an individual volume of 3.7 and $1.4 \mathrm{~m}^{3}$.ind ${ }^{-1}$, respectively, was observed at the ages of 87 and 106 years.
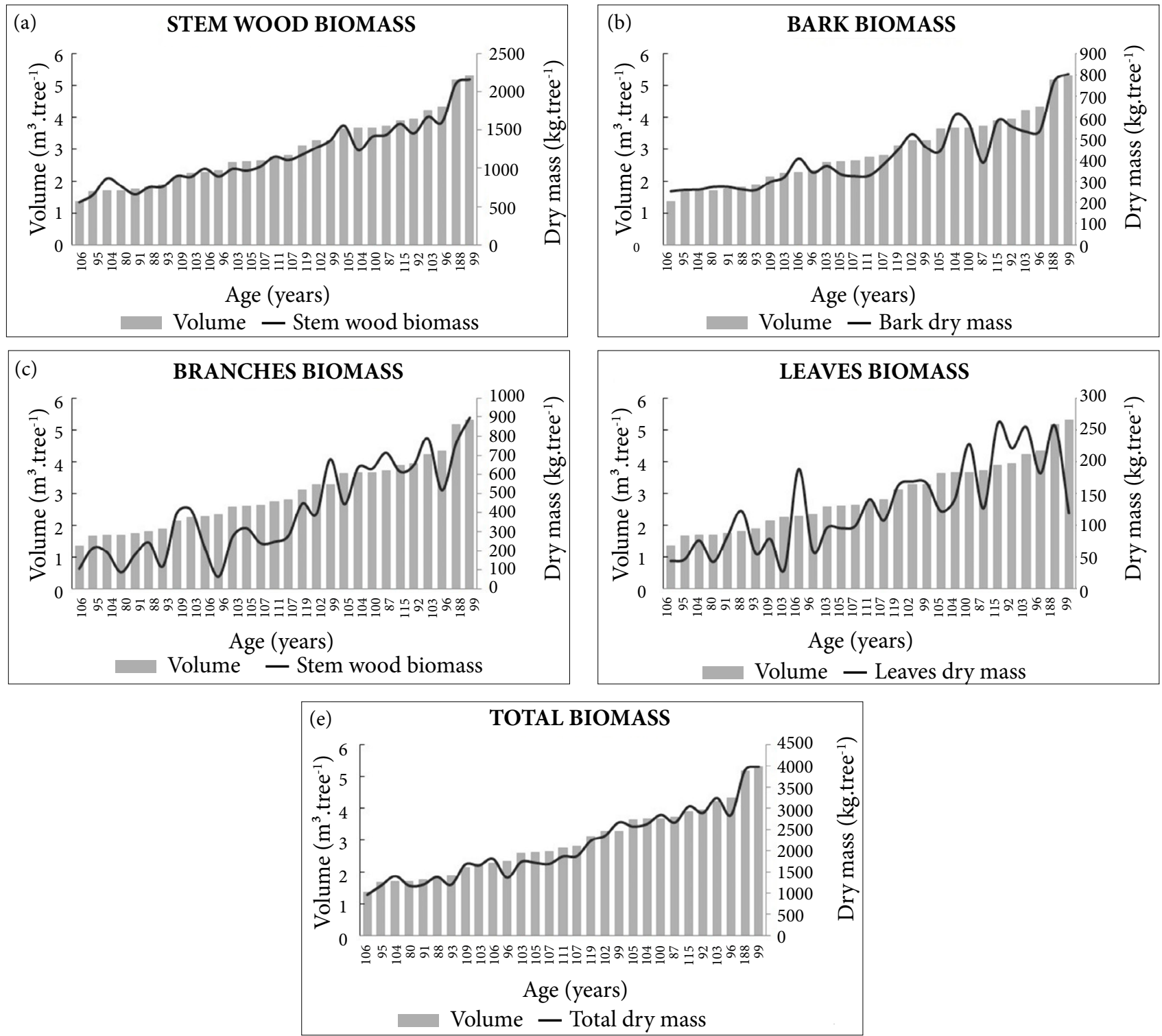

Figure 1. Age, volume, total individual biomass and by component of Araucaria angustifolia. 
Although indicating a positive relation with the volume, the biomasses related to the branches and leaves components presented many oscillations. In this sense, conditions that affect canopy growth have a greater influence on the total amount of biomass of these components in comparison to the production in volume.

For Lamprecht (1990), tree growth is defined by the species' genetic composition and can be influenced by the characteristics of this species interacting with the environment. According to Husch et al. (1982), environmental influences include climatic factors (temperature, precipitation, wind and sun exposure), pedological factors (physical and chemical characteristics, moisture and microorganisms), geomorphological characteristics (inclination, exposure, elevation and shape) and competition (influence of other trees, the understory and animals).

It is observed that stem wood and stem bark biomass and volume have the same growth tendency, meaning that the increase in the volume entails in a greater amount of dry biomass of the stem. However, some trees with higher volume presented lower biomass of these components. In these cases, the age and density of wood mean that individuals with less or equal volume, although with greater age and consequently higher wood density (Brasil et al., 1980), present higher biomass for these components.

In studying the aboveground biomass production in the Montane Mixed Ombrophilous Forest in General Carneiro, PR, Caldeira et al. (2004) found a total of 210.4 t.ha $^{-1}$. Of this total, $A$. angustifolia contributed $23.8 \%$ of the aboveground biomass. Based on the average biomass obtained in the present study, 99 ind.ha ${ }^{-1}$ and 24 ind.ha ${ }^{-1}$ of the species would be respectively required to accumulate the aboveground biomass equivalent to that of the referred phytophysiognomy and the relative percentage to the A. angustifolia species, respectively.

Forest fragments present great variation in both their structure and in their composition. In this sense, a great variation in the density of $A$. angustifolia species in different Mixed Ombrophilous Forest fragments is observed, being found from 42 ind.ha $^{-1}$ (Figueiredo Filho et al., 2010), 57 ind. ha $^{-1}$ (Beckert et al., 2014), to 128 ind.ha ${ }^{-1}$ and 165 ind.ha $^{-1}$ (Sanquetta, Dalla Corte et al., 2003). Care should therefore be taken in using the results obtained for different forest types and the conditions of those that are being compared or even estimated. Therefore, prediction of biomass and carbon in fragments of Araucaria forest should separately consider the A. angustifolia species from the others, given the importance of this species in the composition of this phytogeographic unit. Regarding this idea, Koehler et al. (2005) commented that when evaluating different methods to determine biomass and carbon accumulation, it is ideal to apply a mathematical model for each forest type and for each site, and the use of mathematical models is only valid for the studied and considered conditions, since the results may vary between different types of vegetation, as well as other methods of determining the variables (biomass and organic carbon).

The large accumulation of biomass and carbon by native A. angustifolia trees presented in this research should subsidize carbon credits as an incentive for the conservation of the species and for Mixed Ombrophilous Forest fragments.

\section{CONCLUSIONS}

The native A. angustifolia individuals accumulated an average of 2,126.5 and $935.8 \mathrm{~kg}^{-1 n \mathrm{nd}^{-1}}$ of aboveground biomass and organic carbon, respectively, with the highest allocation being observed in the stem woody component, followed by the stem bark, branches, and leaves components.

Regarding correlation of measurements, the age factor did not result in higher volume production or aboveground biomass and organic carbon in the evaluated trees. The increase in volume resulted in a greater amount of stem wood and bark dry biomass. Factors affecting crown growth have a greater influence on the total biomass of branches and leaves compared to volume and age. Moisture and organic carbon contents varied little between the DBH classes and the evaluated components.

\section{ACKNOWLEDGEMENTS}

To all those involved and partners in the project "Strategies for sustainable forest management in small rural properties in mid-south Paraná”.

\section{SUBMISSION STATUS}

Received: 5 Mar. 2018

Accepted: 25 July 2018

Associate editor: Rodrigo Studart Corrêa

(D) 0000-0002-9422-2629

\section{CORRESPONDENCE TO Mailson Roik}

Universidade Federal do Paraná (UFPR), Av. Pref. Lothário Meissner, 632, CEP 80210-170, Curitiba, PR, Brasil

e-mail: mailsonroik@hotmail.com

\section{REFERENCES}

Balbinot R, Koehler HS, Watzlawick LF, Marcene EA. Ajuste de equações alométricas para Araucaria angustifolia (Bert.) O. Ktze. utilizando análise de componentes principais conjuntamente com análise de regressão. Floresta 2009; 39(2): 232-237. 
Barni PE, Manzi AO, Condé TM, Barbosa RI, Fearnside PM. Spatial distribution of forest biomass in Brazil's state of Roraima, northern Amazonia. Forest Ecology and Management 2016; 377: 170-181. $10.1016 /$ j.foreco.2016.07.010

Barros NF, Novais RF. Eucalypt nutrition and fertilizer regimes in Brazil. In: Attiwill PM, Adams MA, editors. Nutrition of eucalyptus. Melbourne: CISRO; 1996. p. 335-355.

Beckert SM, Rosot MAD, Rosot NC. Crescimento e dinâmica de Araucaria angustifolia (Bert.) O. Ktze. em fragmento de Floresta Ombrófila Mista. Scientia Forestalis 2014; 42(102): 209-218.

Brasil MAM, Nicollelo N, Veiga RAA. Variação da densidade básica da madeira de Pinus oocarpa Schiede em diversas idades na região de Agudos - SP. Floresta 1980; 11(1): 33-39. 10.5380/rf.v11i1.6253

Caldeira MVW, Soares RV, Watzlawick LF. Estimativa de biomassa em espécies arbóreas da Floresta Ombrófila Mista Montana General Carneiro - PR. Biomassa e Energia 2004; 1(3): 291-310.

Caldeira MVW, Watzlawick LF, Viera M, Balbinot R, Castro KC. Biomassa e carbono orgânico em povoamentos de Araucaria angustifolia (Bertol.) Kuntze. Ciência Florestal 2015; 25(4): 1027 1034. $10.5902 / 1980509820664$

Dallagnol FS, Mognon F, Sanquetta CR, Dalla Corte AP. Teores de carbono de cinco espécies florestais e seus compartimentos. Floresta e Ambiente 2011; 18(4): 410-416. 10.4322/floram.2011.060

Djomo NA, Chimi CD. Tree allometric equations for estimation of above, below and total biomass in a tropical moist forest: Case study with application to remote sensing. Forest Ecology and Management 2017; 391(1): 184-193. 10.1016/j.foreco.2017.02.022

Dlugokencky E, Tans P. Trends in atmospheric carbon dioxide [Internet]. [2017?] [cited 2017 Aug. 8]. Available from: https://bit.ly/2pcrBVs

Figueiredo Filho A, Dias AN, Stepka TF, Sawczuk AR. Crescimento, mortalidade, ingresso e distribuição diamétrica em Floresta Ombrófila Mista. Floresta 2010; 40(4): 763-776. 10.5380/rf.v40i4.20328

Figueiredo Filho A, Retslaff FAS, Kohler SV, Becker M, Brandes D. Efeito da idade no afilamento e sortimento em povoamentos de Araucaria angustifolia. Floresta e Ambiente 2015; 22(1): 50-59. 10.1590/2179-8087.080114

Gonçalves JLM, Stape JL, Benedetti V, Fessel VAG, Gava JL. An evaluation of minimum and intensive soil preparation regarding fertility and tree nutrition. In: Gonçalves JLM, Benedetti V, editors. Forest nutrition and fertilization. Piracicaba: IPEF; 2004. p. 13-64.

Henry M, Besnard A, Asante WA, Eshun J, Adu-Bredu S, Valentini $\mathrm{R}$ et al. Wood density, phytomass variations within and among trees, and allometric equations in a tropical rainforest of Africa. Forest Ecology and Management 2010; 260(8): 1375-1388. 10.1016/j. foreco.2010.07.040

Higuchi N, Carvalho JA Jr. Fitomassa e conteúdo de carbono de espécies arbóreas da Amazônia. In: Seminário Emissão x Sequestro de $\mathrm{CO}_{2}$ - Uma nova oportunidade de negócios para o Brasil, Rio de Janeiro, 1994. Anais... Rio de Janeiro: CVRD/FBDS; 1994.

Husch B, Miller CI, Beers TW. Forest mensuration. 3rd ed. New York: John Wiley \& Sons; 1982.

Instituto Brasileiro de Geografia e Estatística - IBGE. Cidades [Internet]. [2017?] [cited 2017 Aug. 22]. Available from: https://bit.ly/2qI6quG

Ketterings QM, Coe R, Noordwijk MV, Ambagau Y, Palm CA. Reducing uncertainty in the use of allometric biomass equations for predicting above-ground tree biomass in mixed secondary forests. Forest Ecology and Management 2001; 146(1): 199-209.

Koehler HS, Watzlawick LF, Kirchner FF, Valério AF. Fontes de erros nas estimativas de biomassa e carbono fixado na Floresta Ombrófila Mista. Biomassa e Energia 2005; 2(1): 69-77.

Lamprecht H. Silvicultura nos trópicos. Eschborn: GTZ; 1990.

LECO. C-144 Carbon Determinator: Specification Sheet 209-134-003. St. Joseph: LECO Corporation; 2008.

Lima AJN, Suwa R, Ribeiro GHPM, Kajimoto T, Santos J, Silva RP et al. Allometric models for estimating above- and below-ground biomass in Amazonian forests at São Gabriel da Cachoeira in the upper Rio Negro, Brazil. Forest Ecology and Management 2012; 277(1): 163-172. 10.1016/j.foreco.2012.04.028

Mognon F, Dallagnol FS, Sanquetta CR, Dalla Corte AP, Barreto TG. Uma década de dinâmica de fixação de carbono na biomassa arbórea em Floresta Ombrófila Mista no Sul do Paraná. Floresta 2013; 43(1): 153-164. 10.5380/rf.v43i1.29024

Nogueira EM, Fearnside PM, Nelson BW, Barbosa RI, Keizer EWH. Estimates of forest biomass in the Brazilian Amazon: New allometric equations and adjustments to biomass from wood-volume inventories. Forest Ecology and Management 2008; 256(11): 18531867. 10.1016/j.foreco.2008.07.022

Painel Brasileiro de Mudanças Climáticas - PBMC. Base Científica das Mudanças Climáticas. Contribuição do Grupo de Trabalho 1 do Painel Brasileiro de Mudanças Climáticas ao Primeiro Relatório de Avaliação Nacional sobre Mudanças Climáticas. Ambrizzi T, Araujo M, editors. Rio de Janeiro: COPPE, Universidade Federal do Rio de Janeiro; 2014a. 464 p.

Painel Brasileiro de Mudanças Climáticas - PBMC. Impactos, vulnerabilidades e adaptação às mudanças climáticas. Contribuição do Grupo de Trabalho 2 do Painel Brasileiro de Mudanças Climáticas ao Primeiro Relatório da Avaliação Nacional sobre Mudanças Climáticas. Assad ED, Magalhães AR, editors. Rio de Janeiro: COPPE, Universidade Federal do Rio de Janeiro, 2014b. 414 p.

Sanquetta CR, Dalla Corte AP, Eisfeld RL. Crescimento, mortalidade e recrutamento em duas florestas de Araucária (Araucaria angustifolia (Bert.) O. Ktze.) no estado do Paraná, Brasil. Revista Ciências Exatas e Naturais 2003; 5(1): 101-112.

Sanquetta CR, Dalla Corte AP, Mognon F, Maas GCB, Rodrigues AL. Estimativa de carbono individual para Araucaria angustifolia. Pesquisa Agropecuária Tropical 2014; 44(1): 1-8. 10.1590/S198340632014000100006

Sanquetta CR, Watzlawick LF, Schumacher MV, Mello AA. Relações individuais de biomassa e conteúdo de carbono em plantações de Araucaria angustifolia e Pinus taeda no sul do estado do Paraná, Brasil. Revista Acadêmica 2003; 1(3):33-40. 10.7213/cienciaanimal.vli3.14937

Sanquetta CR, Wojciechowski J, Dalla Corte AP, Rodrigues AL, Maas GCB. On the use of data mining for estimating carbon storage in the trees. Carbon Balance Management 2013; 8(6): 1-9. 10.1186/17500680-8-6

Sanquetta CR, Wojciechowski J, Dalla Corte AP, Behling A, Péllico Netto S, Rodrigues AL et al. Comparison of data mining and allometric model in estimation of tree biomass. BMC Bioinformatics 2015; 16: 247. 10.1186/s12859-015-0662-5

Schoeninger ER, Koehler HS, Watzlawick LF, Oliveira Filho PC. Uso de redes neurais artificiais como uma alternativa para mapeamento 
de biomassa e carbono orgânico no componente arbóreo de florestas naturais. Ambiência 2008; 4(3): 529-549.

Schumacher MV, Caldeira MVW. Estimativa da biomassa e do conteúdo de nutrientes de um povoamento de Eucalyptus globulus (Labillardière) sub-espécie maidenii. Ciência Florestal 2001; 11(1): 45-53. 10.5902/19805098494

Schumacher MV, Witschoreck R, Calil FN, Lopes VG. Biomassa e nutrientes no corte raso de um povoamento de Pinus taeda L. de 27 anos de idade em Cambará do Sul - RS. Ciência Florestal 2013; 23(2): 321-332. 10.5902/198050989278

Schumacher MV, Witschoreck R, Calil FN, Lopes VG, Viera M. Produção de biomassa no corte raso em plantio de Araucaria angustifolia (Bertol.) Kuntze de 27 anos de idade em Quedas do Iguaçu, PR. Ciência Florestal 2011; 21(1): 53-62. 10.5902/198050982747

Silveira P, Koehler HS, Sanquetta CR, Arce JE. O estado da arte na estimativa de biomassa e carbono em formações florestais. Floresta 2008; 38(1): 185-206. 10.5380/rf.v38i1.11038

Socher LG, Roderjan CV, Galvão F. Biomassa aérea de uma Floresta Ombrófila Mista Aluvial no município de Araucária (PR). Floresta 2008; 38(2): 245-252. 10.5380/rf.v38i2.11619

Watson C. Forest carbon accounting: overview and principles. London: UNDP, UNEP; 2009.

Watzlawick LF, Caldeira MVW, Godinho TO, Balbinot R, Trautenmuller JW. Aboveground stock of biomass and organic carbon in stands of Pinus taeda L. Cerne 2013; 19(3): 509-515. 10.1590/S0104-77602013000300019

Watzlawick LF, Caldeira MVW, Viera M, Schumacher MV, Godinho TO, Balbinot R. Estoque de biomassa e carbono na Floresta Ombrófila Mista Montana, Paraná. Scientia Forestalis 2012; 40(95): 353-362.

Watzlawick LF, Ebling AA, Rodrigues AL, Veres QJI, Lima AM. Variação nos teores de carbono orgânico em espécies arbóreas da Floresta Ombrófila Mista. Floresta e Ambiente 2011; 18(3): 248-258. 10.4322/floram.2011.045

Watzlawick LF, Kirchner FF, Sanquetta CR. Estimativa de biomassa e carbono em floresta com araucária utilizando imagens do satélite IKONOS II. Ciência Florestal 2009; 19(2): 169-181. 10.5902/19805098408

Watzlawick LF, Sanquetta CR, Arce JE, Balbinot R. Quantificação de biomassa total e carbono orgânico em povoamentos de Araucaria angustifolia (Bert) O. Kuntze no sul do estado do Paraná, Brasil. Revista Acadêmica: Ciências Agrárias e Ambientais 2003; 1(2): 63-68. 10.7213/cienciaanimal.v1i2.14919

Weber KS, Sanquetta CR, Mello AA, Watzlawick LF, Balbinot R. Variação nos teores de carbono orgânico em povoamentos de Araucaria angustifolia (Bert.) O. Ktze. Brasil Florestal 2003; 22(76): 23-28.

Wrege MS, Steinmetz S, Reisser C Jr, Almeida IR. Atlas climático da região sul do Brasil: estados do Paraná, Santa Catarina e Rio Grande do Sul. Pelotas: Embrapa Clima Temperado; Colombo: Embrapa Florestas; 2012. 